\title{
Empowering community through creative economy as a disaster risk reduction strategy in Indonesia
}

\author{
Ratna W.D.P ${ }^{1^{*}}$, Noviansyah Rizal $^{1}$, Riza B.S ${ }^{1}$, Fauziyah $^{2}$, and Muhammad Dimyati ${ }^{3}$ \\ ${ }^{1}$ Institut Teknologi dan Bisnis Widya Gama, Accounting Department, Lumajang East Java Province, Indonesia \\ ${ }^{2}$ University of Science and Technology Beijing, Department of Computer and Communication Engineering, Beijing, China \\ ${ }^{3}$ Institute of Economic Science Mandala, Accounting Department, Jember East Java Province, Indonesia
}

\begin{abstract}
In the 21st century, the world is faced with COVID-19 global pandemic that has had wideranging health, social, food, and economic negative impacts throughout the world and also in Indonesia due to the cessation of the mobility of most people and economic engines. The creative empowers the community based on innovation and creativity proven and is one of the pillars of disaster risk reduction recovering the social and economic impact of COVID-19 in the community. The method used is an ethnographic approach starting from the collection of literature sources and supported by field data. The results show that the concept of the creative economy is creative ideas developed by humans supported by the use of technology to produce innovative products and cultures, having regional imagery but are globally competitive and can ultimately provide value to the national economy. Intellectual actors included are not only academics but also include industry players, pioneers, figures in the arts, culture, and sciences who have a role in providing creative ideas, innovations in the creative industry. The result is a triplex helix model in mitigating the effect of the covid19 disaster by connecting intellectuals, businesses, and the government in a creative economic structure.
\end{abstract}

\section{Introduction}

The Indonesian government has set targets to support an inclusive and sustainable national economy, a full and productive workforce, and decent work for all. The government has designed and implemented policies that support sustainable tourism that enable the creation of jobs while supporting local culture and products by 2030 [1]. However, the spread of covid-19 has a disastrous impact on local and national economies around the world, many industries and policymakers are researching the impact of covid-19 on the creative and cultural industries, as well as workers in the sector [2].

The global recession caused by covid19 reduce consumption and investment in various countries. In Indonesia in the second quarter of 2020, Indonesia's economic growth was depressed to a negative 5.32\% (yoy) compared to the same period last year. This contraction is more than in the previous quarter of $2.97 \%$. Only China started showing positive growth to $3.2 \%$ in the second quarter of 2020 . Whereas in the first quarter of 2020 , economic growth was negative up to $6.8 \%$.

The development of a local culture-based creative economy ecosystem, supported by competent business actors, requires support and cooperation from several parties including the government, the private sector, community, academia, as well as the media. In addition, the development of the sector can also be carried out with training to improve the welfare of business actors ([3].

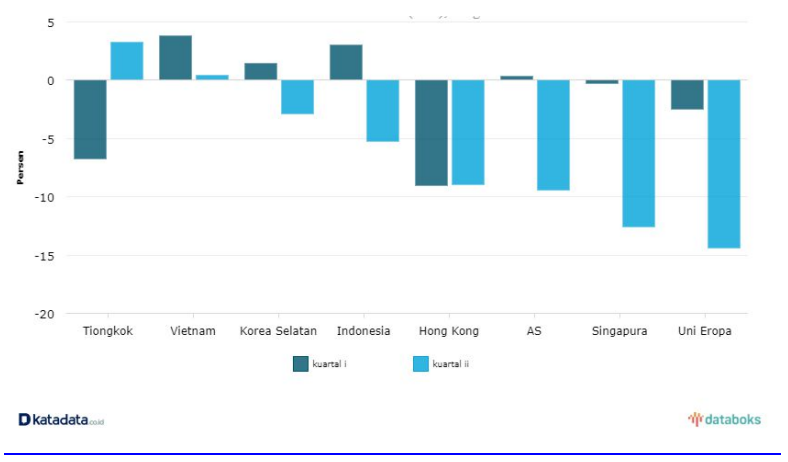

Fig. 1. 2020's Global Economic Growth (YoY)

The creative economy has been widely developed in major countries such as the US, UK [4], all countries in Australia [5], including in Indonesia [6]. Optimizing the creative economy in Indonesia has become the focus of researchers in recent years [7]. There are challenges concerning creativity and culture that are widely recognized in the academic world. However, it is often invisible to policymakers ([2]. The most populous

\footnotetext{
* Corresponding Author: pradnyataj@gmail.com
} 
population in Indonesia is on the island of Java, along with its potential for cultural diversity and creative economic activities. Local wisdom and cultural events reflect the creativity of the community and can provide economic value for the community [8].

The creative economy has started to be discussed in Indonesia and has received proper facilities since 2006. The creative economy has contributed significantly to the economic development in Indonesia. Following the growing business world, the creative economy will also continue to develop along with the increasing creativity of business actors. In the future, it is expected that the creative industry can grow bigger and wider. The government provides various support and assistance for the development of the creative economy and development of this business. The government also holds various important events as a means of exhibiting products created by the community's creativity.

Based on the results of research between the Creative Economy Agency (Bekraf) and the Central Statistics Agency (BPS) in 2016, the creative economy contributed to the national economic growth of 922.59 billion rupiahs or 7.44 percent of the national Gross Domestic Product (GDP). Numerous empirical evidence supports that the creative industry has an impact on GDP through the creative industry sub-sector and creates a new form of governance of the cultural industry.

There are six main characteristics of the creative economy as quoted from Creative Economy Based on Local Wisdom in 2020. First is the existence of creative economy intellectual creations, emphasizing the importance of creativity. Therefore, creativity and expertise in a sector are a necessity and become one of the main characteristics of the creative economy. Second is the nature of easy to replace. Creations and innovations must continue to be developed under the development of the economic activity. The goal is to be accepted by the market and useful for the consumers. The third is the direct and indirect distribution based on company policies and consumer needs. Fourth, is the requirement of cooperation between all parties, such as between the entrepreneur and the government that regulates the policy. Fifth is based on ideas, that ideas are vital in developing creative industries and will always be related to innovation and creativity. The sixth is the nature of no limitation in product creation which means that innovation and creativity in product creation will always occur and has no definite limits.

This research focuses more on innovation and creativity to be developed, which is necessary for the growth of the creative industry in Indonesia. The result shows that the Indonesian economy can compete with other countries and will automatically become an indication that the Indonesian creative economy is one step ahead of its competitors

\section{Method}

This study uses an ethnographic approach. The ethnographic method [9] started with literature sources and was complemented by field data obtained through observation, participation, and in-depth interviews with selected respondents. Literature sources are obtained from researches that have been carried out starting in 2017 on culture in Banyuwangi. Informants are determined based on their involvement and role in the development of the creative industry, MSME actors, the community, and local government. The validation of the data is performed using triangulation of sources. Data analysis is carried out thoroughly and continuously starting from the process of data inventory, identification, classification, and data interpretation. Interpretation of data is carried out comprehensively by looking at the overall relationship of the data.

There are two approaches used in community development, the direct and indirect approaches [10]. The direct approach is carried out by implementing community empowerment, while the indirect approach is carried out with a process of public awareness of the importance of developing creative industries. The model developed is a participatory cycle model, which includes processes that are carried out simultaneously starting from input, process, output, impact, and result.

\section{Result and Discussion}

The creative industries in Banyuwangi include several creative industries spread across various regions and contribute significantly to the regional economy. One of the creative industries that are developing is the bamboo handicrafts - crafts that use natural products to be used as household products, household accessories, fashion, musical instruments, and others. The creative industry of bamboo handicrafts has shown an increasing trend, attracting the market and opening up wide business opportunities. In certain areas, such as Papring has its prosperous resources of bamboo raw materials. The bamboo craft equipped with ideas and creativity will be able to produce products that are competitive in the global market. Communities in the Papring have started their activities to develop their potential by utilizing the natural potential in their environment by producing handicrafts from bamboo. Papring area has abundant various types of bamboo such as their unique origin Panggonane Pring, which is the source of bamboo plants. The types of bamboo in this area include stone bamboo, apus, petung, nineg, and various other types. The bamboo crafts industry is self-sufficient in terms of raw materials since it did not require supplies from outside of the region for handicraft production.

The Triple Helix concept integrates the roles of academia, business, and government into creativity, innovation, and technology activities for the creative industry. The creativity and innovation have a close relationship that supports innovation performance. Carayannis and Campbell (2009) stated the importance of government, university, and industry policies and practices to interact intelligently, effectively, and efficiently.

The role of intellectuals is to spread and implement science, art, and technology and to form constructive values for the development of creative industries in 
society. Intellectuals are related to new creating activities that have the bargaining power to the market and the formation of creative people. Academics as part of intellectuals have 3 roles, namely, the role of education aimed at encouraging the birth of future creative generations that support the creation, innovation, and work in the creative industry. The role of research is carried out to provide input on creative industry development policy models and their required instruments, manage the renewal of ideas and creative processes that will produce new products, services, and technology that supports efficient working and use of resources and makes a competitive national creative industry. The role of community service is carried out in forming a society with social institutions and social orders that support the growth of the national creative industry. In realizing the importance of innovation performance in the creative industry, it is necessary to measure the performance of innovation that is appropriate for business actors in the creative industry.

Intellectual actors are not only academics but also include culturalists, artists, writers, pioneers, figures in the arts, culture, and sciences whom all have their roles in providing creative ideas, innovations in the creative industry.

The business becomes a liaison in the context of economic exchange and the transformation of creativity into economic value. The business function as actors, investors, and creators of new technology, as well as consumers. The creative industry serves as the center of excellence of creators of products, services, and creative culture, as a new market that absorbs products produced and created new jobs for creative individuals or other supporting individuals. The business also plays a role as a community and creative entrepreneur builder which function as a motor that forms a space for thinking, honing creative ideas in doing creative industry business, as well as business coaching or business management training in the creative industry.

The Government has a major role in the mechanism for providing incentive programs, controlling a conducive business climate, educative directions as well as supporting the development of creative industries for the community and the private sector. The government also acts as a catalyst and facilitator and advocate that provides stimulation, challenges, and encouragement in the development of creative industries so that innovative ideas move to a higher level of competence. This support can be in the form of the government's commitment to using its political power proportionally and by providing good public administration services in addition to financial assistance, incentives, or protection. The government also acts as a regulator that produces policies related to society, industry, institutions, intermediation, and resources and technology. The government can accelerate the development of the creative industry if they were able to make policies that create a conducive business climate for the creative industry. The government as an investor must be able to empower the state's assets to be productive within the scope of the creative industry and to be responsible for industrial infrastructure investment.
In the creative industry, the government makes a model based on creative individuals with five main pillars, namely: (1) industries involved in the production of creative industries; (2) technology as a supporter of the realization of individual creativity; (3) resources required such as natural resources and land; (4) institutions ranging from norms and values in society, industry associations and supporting communities to the protection of intellectual property; and (5) financial intermediary institutions.

\section{Conclusion}

The Indonesian sustainable tourism policy goals of 2030 which support that enable the creation of jobs while supporting local culture and products have their challenges with the spread of covid-19. Based on the Triple Helix concept for the creative industry, the roles of academia, business, and government in creativity, innovation, and technology activities to interact intelligently, effectively, and efficiently as required for such goal.

With its nature as being the largest archipelagic country in the world, Indonesia has the potential for a creative economy in terms of unique resources, language, and culture with the support of intellectuals such as academics, culturalists, artists, writers, pioneers, figures in the arts, culture, and sciences whom all have their roles in providing creative ideas, innovations in the creative industry. Academics intellectuals serve their roles in education, research, and community service. The business becomes a liaison in the context of economic exchange and the transformation of creativity into economic value, while the Government has its major role as major support of financial assistance, regulator, business climate, educative directions, catalyst, facilitator, and advocate of creative industries. The development of a local culturebased creative economy ecosystem, supported by competent business actors, requires support and cooperation from several parties including the government, the private sector, community, academia, as well as the media.

\section{References}

1. R. B. Sulistyan, \& R. W. Paramita,. D. Business Location Planning Assistance: Preservation of Traditional Culture of Kampoeng Batara Banyuwangi. Empowerment Society, 4 (1), 17-21. (2021)

2. R. Comunian,\& L. England,. Creative and cultural work without filters: Covid-19 and exposed precarity in the creative economy. Cultural Trends, 29 (2), 112-128. (2020)

3. I. Hilmiana, Soemaryani, \& A. R. Prasetyo,. Strategic Partnership Model In Developing The Local Art And Culture-Based Creative Economy. Academy of Strategic Management Journal, 20 (1), 1-9(2021)

4. T. Kemeny, M. Nathan, , \& D. O’Brien,. Creative differences? Measuring creative economy 
employment in the United States and the UK. Regional Studies, 54 (3), 377-387. (2020)

5. S. Cunningham, M. McCutcheon, G. Hearn, \& M. D. Ryan,. 'Demand' for culture and 'allied' industries: policy insights from multi-site creative economy research. International Journal of Cultural Policy, 114. (2020)

6. Y. Agustina, A. Winarno, H. Pratikto, B. S. Narmaditya, \& F. Filianti,. A Creative Economy Development Strategy: The Case of Trenggalek Creative Network for Trenggalek Regency, Indonesia. The Journal of Asian Finance, Economics and Business, 7 (12), 1111-1122.(2020)

7. S. Madelan,. Optimizing Exports of Indonesian Creative Economy Products Towards Increasing Competitiveness. Journal of Business Economics,
Communication, and Social Sciences (BECOSS), 2(3), 273-284. (2020)

8. N. Nurdiani, R. Hendarti, , \& M. Tedja,. Physical Quality of Creative Economic Space on Cultural Tourism Areas in Java Island. IOP Conference Series: Earth and Environmental Science, 452, 012057. (2020)

9. Spradley, Metode Etnografi. Yogyakarta: PT Tiara J. P.Wacana. (1997)

10. N. Anoegrajekti, Asrumi, Macaryus, S., Iskandar, I., Attas, S. G., Sunarti, S., \& Saddhono, K.. Optimization Pillars of Potential Culture and Creative Industry in Banyuwangi, East Java, Indonesia. Psychology and Education, 58 (3), 20252032 (2021) 